\title{
Konsep Diri Perempuan di Kawasan Rawan Bencana Gunung Merapi
}

\section{Mario Antonius Birowo ${ }^{1}$, Dhyah Ayu Retno Widyastuti², Thomas Adi Purnomo Sidhi ${ }^{3}$}

\author{
Program Studi Ilmu Komunikasi, FISIP ${ }^{1,2}$; Program Studi Teknik Informatika, FTI ${ }^{3}$ \\ Universitas Atma Jaya Yogyakarta \\ birowo@staff.uajy.ac.id; dhyah.ayurw@yahoo.com; th.adi.ps@staff.uajy.ac.id
}

\begin{abstract}
The participation of communities in disaster areas is one of the important factors of disaster management. Complexity in the disasters area affects social dynamics. The most vulnerable group in a community are women, whether the physical and psychological condition. In the context of disaster risk reduction, it is important to consider the condition of women. To understand the phenomena, this research uses Self-concept, which is discussed by George Herbert Mead in his Interaction Symbolic Theory. This research uses descriptive_qualitative method about the women in four villages on the slope of Merapi volcano, Boyolali, Central Java. These villages are located in a dangerous area during the last Merapi's eruption. Data were collected by some techniques, such as Focus Group of Discussion, interview, document, and observation. This research found the uniqueness selfconcept of women about marriage underage, the need of education, and economic sustainability.
\end{abstract}

Keywords: Self Concept, Women, Disaster Area, Merapi Mountain

\begin{abstract}
Abstraksi
Keterlibatan masyarakat merupakan salah satu faktor penting dalam upaya penanggulangan bencana. Kompleksitas yang ada di wilayah bencana mempengaruhi berbagai dinamika masyarakat. Salah satu yang paling rentan adalah pengaruh pada perempuan dan anak. Kondisi fisik maupun psikologis menjadi persoalan krusial pada perempuan di wilayah rawan bencana. Pelibatan dalam upaya penanganan pengurangan risiko bencana (PRB) tentu didasari oleh keadaaan dari masingmasing individu. Penelitian ini bertujuan menemukan konsep diri perempuan di kawasan rawan bencana. Teori interaksi simbolis yang dikembangkan oleh George Herbert Mead digunakan sebagai pijakan penulis dalam mengembangkan ide dan paparan pembahasan. Metode penelitian yang digunakan adalah deskriptif kualitatif yang dilakukan pada kelompok perempuan di empat desa di Kecamatan Selo, Kabupaten Boyolali. Kecamatan ini merupakan satu wilayah yang terdampak besar saat terjadi bencana alam di Gunung Merapi. Pengumpulan data dilakukan melalui wawancara dan Focus Group Discussion. Triangulasi sumber data dilakukan untuk validitas data temuan. Hasil penelitian menunjukkan konsep diri perempuan di wilayah rawan bencana memandang cenderung berfikir konservatif, pernikahan dini banyak terjadi, keterbatasan akses pendidikan dan kapasitas ekonomi.
\end{abstract}

Kata Kunci: Konsep Diri, Perempuan, Rawan Bencana, Gunung Merapi

\section{Pendahuluan}

Peran aktif perempuan dalam Pengurangan Risiko Bencana (PRB) merupakan hal yang sangat penting untuk ditingkatkan mengingat perempuan merupakan pihak yang rentan terkena bencana. PRB sangat lekat dengan akses informasi karena informasi akan membantu warga untuk bertindak tepat dan sesegera mungkin untuk terhindar dari bencana sehingga akan terjadi pengurangan risiko.

Banyak peristiwa bencana alam di Indonesia terkait dengan posisi Indonesia di pertemuan tiga lempeng/plates: Eurasian Continental, Indo-Australian Oceanic dan Pacific Oceanic. Posisi ini menyebabkan 
Indonesia memiliki risiko bencana geologis (Amri et al., 2016). Badan Penanggulangan Bencana Nasional (BNPB) mencatat bahwa sepanjang tahun 2017 terjadi 2.271 kejadian bencana (Sulistiyono, 2017), seperti erupsi gunung berapi, kekeringan, tanah longsor, gempa bumi, banjir, dan abrasi.

Sebuah bencana alam dapat mengganggu kemajuan ekonomi dan sosial masyarakat. Kerusakan yang ditimbulkan berbagai bencana alam seperti gempa bumi, letusan gunung berapi, tanah longsor, tsunami, banjir atau kekeringan berdampak serius terhadap masyarakat atau wilayah yang terkena. Pada daerah bencana selalu ada kebutuhan mendesak untuk informasi untuk mengevaluasi situasi, mencari tahu bagaimana untuk mendapatkan bantuan, dan cara terbaik untuk menggunakan bantuan. Konteks ini, peran komunikasi sosial untuk memberikan informasi kepada mereka yang terkena dampak sangat penting untuk koordinasi antara orang-orang lokal (korban), instansi pemerintah dan bantuan (Tanesia, 2007).

Undang Undang Penanggulangan Bencana No. 4 Tahun 2007 menyatakan bahwa penanggulangan bencana menjadi tanggung jawab pemerintah. Peran serta masyarakat sangat penting, hal ini disebabkan masyarakat menduduki posisi di garis depan saat bencana, artinya yang paling terkena dampak bencana. Faktor lain yakni adanya keterbatasan pemerintah dalam menjangkau suatu wilayah secara cepat sehingga pengurangan risiko bencana sangat penting untuk mempertimbangkan partisipasi masyarakat. Dalam konteks kebencanaan, partisipasi masyarakat akan efektif jika didukung oleh pengetahuan tentang komunikasi kebencanaan (Lestari, Kusumayudah, Paripurno \& Jayadianti, 2016). Komunikasi kebencanaan tersebut membutuhkan kecepatan dalam distribusi informasi yang didukung oleh infrastruktur yang sesuai dengan lokasi bencana (Kusumayudha, Lestari \& Paripurno, 2018)

Salah satu kelompok yang rentan dalam wilayah bencana adalah perempuan (ESCAP \& UNISDR, 2012; Hazeleger, 2013). Kondisi perempuan terkait budaya, kapasitas menyelamatkan diri serta mobilitas perempuan menyebabkannya berada dalam situasi rentan ketika berhadapan dengan bencana (Kibria, 2016). Perbedaan fisik, biologis, norma sosial serta status ekonomi perempuan menyebabkan bencana berdampak berbeda antara perempuan dan laki-laki (Ashraf \& Azad, 2015; Neumayer \& Plümper, 2007). Pada kajian ini menekankan pada dinamika antara perempuan yang dianggap memiliki kerentanan lebih tinggi dibandingkan dengan laki-laki. Berdasarkan hasil penelitian yang telah ada sebelumnya, apabila dilihat dalam lingkup masyarakat secara spesifik berdasarkan jenis kelamin, perempuan merupakan personal yang rentan terhadap risiko terjadinya bencana. Baik dalam hal kebutuhan fisik maupun pendampingan secara psikologis. Satu tugas bersama dalam memberi pendampingan kepada komunitas ini untuk lebih bisa secara personal mampu mengelola dan mempersiapkan risiko yang akan dihadapai ketika kondisi bencana terjadi.

Berbicara mengenai manajemen kebencanaan tidak dapat dipisahkan 
dengan risiko yang hadir pada masyarakat. Bila ditinjau dari aspek jenis kelamin antara perempuan dan laki-laki maka perempuan memiliki risiko yang lebih tinggi dibandingkan laki-laki. Kerentanan perempuan ini terkait oleh persoalan kondisi sosial-ekonomi dan budaya yang menempatkan perempuan secara tidak adil (UNESCO, 2014). Sensitivitas kebutuhan pada perempuan kadang diabaikan oleh beberapa pihak dalam penanganan risiko bencana. Manajemen bencana sering melupakan posisi perempuan (Women, 2013). Korban dipandang sebagai single entity sehingga perlakuan terhadap korban tidak membedakan kebutuhan perempuan dan laki-laki (Tanesia, 2007). Senada dengan Tanesia, persoalan tersebut muncul dalam penelitian di Bangladesh (Ashraf \& Azad, 2015). Walau perempuan merupakan aktor penentu terciptanya harmonisasi keluarga, namun kecenderungan asessment yang dilakukan oleh sebagian besar kelompok peduli bencana didominasi oleh laki-laki yang mengandalkan umpan balik dari kepala rumah tangga laki-laki (Enarson, 2009).

UNESCO mencatat bahwa perempuan lebih rentan dalam berhadapan dengan bencana, seperti saat Tsunami 2004, $70 \%$ korban hilang di Asia merupakan perempuan, korban perempuan lebih banyak akibat Huricane Katrina di Amerika Serikat, juga cyclone tahun 1991 di Bangladesh (UNESCO, 2014). Hal ini tentunya manajemen bencana perlu memperhatikan isu gender, sebagaimana agenda SDGs, dalam mengentaskan kemiskinan maupun pada pencapaian kesetaraan gender. Gender menekankan posisi perempuan di dalam masyarakat melalui konstruksi sosial yang dibangun di masyarakat. Gender merujuk pada stereotipe, peran, kesempatan, dan hubungan yang terbentuk secara sosial yang dikaitkan dengan keadaan sebagai female atau male (Pincha, 2008).

Manajemen risiko bencana yang sensitif gender diperlukan untuk menjaga pencapaian tujuan SDGs agar tetap berada di jalurnya. Moreno \& Shaw (Moreno \& Shaw, 2018) menyatakan bahwa penguatan perempuan dalam manajemen bencana akan berakibat pada ketangguhan dan perubahan sosial dalam relasi perempuan dan laki-laki. Laki-laki dan perempuan dapat memainkan peran yang saling melengkapi dalam masa pemulihan pasca bencana: laki-laki umumnya melakukan rekonstruksi fisik, sementara perempuan berkontribusi untuk memperluas dukungan psiko-sosial dan diversifikasi mata pencaharian. Kesadaran dan pengetahuan perempuan sangat penting untuk manajemen risiko yang efektif dalam mempersiapkan rumah tangga, menyimpan stok makanan dan mempertahankan jaringan sosial untuk penyebaran informasi, pendidikan anak-anak dan masyarakat (Kemenpppa, 2011).

Kekhasan penelitian ini dibandingkan dengan studi literatur yang sudah diulas sebelumnya bahwa fokus kajian ini adalah mengenai konsep diri perempuan di kawasan rawan bencana sehingga konsep dasar mengenai konsep diri perlu disajikan dan menjadi pijakan dalam menganalisis realitas yang ditemukan. Konsep diri (Self-concept) dibahas di dalam Interaction Symbolic 
Theory yang awalnya dimunculkan oleh John Dewey dan William James kemudian dikembangkan oleh George Herbert Mead (Chicago University) dan Manford Kuhn (Iowa University). Penelitian ini mengacu pada Interaction Symbolic Theory yang dikembangkan oleh Mead (West \& Turner, 2010). Teori ini memiliki tiga asumsi: pertama, pentingnya makna bagi prilaku manusia; kedua, pentingnya self-concept; dan ketiga, hubungan antara individu dan masyarakat. Asumsi pertama mengatakan bahwa setiap individu membangun makna melalui proses komunikasi. Proses ini melibatkan partisipasi individu-individu untuk melakukan interpretive construction. Ada proses interaksi sosial dalam pemaknaan, sehingga bisa disimpulkan pemaknaan merupakan hasil dari berbagi ide, sekaligus makna yang dihasilkan disebarkan di antara individu-individu. Kata lain, makna terhadap sesuatu merupakan hasil kesepakatan bersama dan digunakan bersama.

Asumsi kedua tentang pentingnya selfconcept menyatakan bahwa setiap individu memiliki persepsi yang relatif stabil tentang diri mereka. Penyebabnya adalah self-concept tidak terjadi secara tiba-tiba, namun hasil proses interaksi individu yang bersangkutan dengan individu-individu lainnya, misalnya dengan keluarga, teman dan guru. Jadi, individu mengembangkan self-concept melalui interaksi orang lain. Konsekuensinya, individu belajar memahami dirinya, tentang siapa dirinya dari interaksi dengan individu lain.

Asumsi ketiga menyatakan bahwa budaya dan proses sosial mempengaruhi individu yang ada di dalamnya. Artinya, individu tidak sepenuhnya bebas dari nilai dan norma yang hidup di masyarakatnya. Pengaruh budaya dan proses sosial terjaga melalui pergaulan di masyarakat (atau social interaction). Persoalan gender muncul sebagai hasil budaya yang melingkupi hidup seseorang, di manaia berinteraksi dan tumbuh sebagai individu. Tidak mengherankan jika kemudian lahirlah stereotip-stereotip gender. Self-concept seseorang tidak terlepas dari stereotip yang dikenalnya. Self-concept yang terbentuk akan mempengaruhi segala motif dari tindakannya (Pincha, 2008).

Terdapat tiga komponen dalam konsep diri, yaitu: (a) attitude yakni sikap seseorang ketika menghadapi suatu kondisi tertentu; (b) beliefs yakni kepercayaan akan penerimaan yang dianggap benar dan (c) values yakni nilai yang menjadi pedoman bagi seseorang ketika melakukan sesuatu dan bertindak (Beebe, Beebe Susan J., \& Diana K Ivy., 2010).

Penelitian ini menyajikan gambaran mengenai hasil penelitian yang menunjukkan berbagai konsep diri yang ada pada perempuan di kawasan rawan bencana. Harapannya bahwa sajian data dan analisisnya mampu memberikan sumbangsih pada pengembangan bidang ilmu komunikasi dalam kajian mengenai konsep diri maupun manajemen risiko bencana secara umum dan persoalan perempuan secara khusus.

\section{Metode Penelitian}

Peneliti menggunakan jenis penelitian kualitatif karena peneliti ingin melihat secara mendalam pola-pola komunikasi yang berlangsung. Penelitian kualitatif membantu peneliti memperoleh informasi 
baru yang bermanfaat bagi studi komunikasi partisipatif (Flick, 2002). Metode yang digunakan adalah deskriptif dimana peneliti memberi gambaran mengenai realitas yang ada pada kelompok sasaran melalui data yang disajikan dalam bentuk verbal maupun non-verbal. Pengumpulan data penelitian menggunakan teknik wawancara, penelusuran dokumen dan observasi. Wawancara dilakukan secara individual kepada pemangku kebijakan di wilayah setempat seperti kadus/ kepala dusun, ketua RT, ketua PKK, ketua organisasi kemasyarakatan lainnya, dan masyarakat setempat. Focus Group Discussion dilakukan untuk menggali data dari subjek penelitian yang merupakan ibu-ibu rumah tangga. Penulusuran dokumen berupa data desa, sedangkan observasi digunakan untuk mengamati kondisi lingkungan dan sumber daya masyarakat yang tinggal di daerah rawan bencana. Teknis analisis data dilakukan dengan tahapan mengumpulkan data di lapangan dan melakukan penyaringan sesuai dengan kebutuhan data yang relevan dengan dinamika masyarakat di daerah rawan bencana Gunung Merapi, selanjutnya dilakukan analisis data berdasarkan konsep teori yang digunakan hingga penarikan kesimpulan. Triangulasi data dilakukan dengan melakukan kroscek antara data yang diperoleh peneliti melalui wawancara di lapangan dengan hasil pengamatan langsung pada kondisi wilayah dan masyarakat secara langsung di lapangan.

\section{Hasil Penelitian Dan Pembahasan}

Lokasi penelitian berjarak $52 \mathrm{Km}$ dari Yogya, atau kurang lebih 90 menit jika ditempuh dengan kendaraan bermotor. Jrakah, Klecoh, Tlogolele dan Klakah merupakan desa-desa yang ada di kecamatan Selo, Kabupaten Boyolali. Sebagian wilayah desa-desa tersebut masuk dalam wilayah Kawasan Rawan Bencana III, wilayah yang dekat dengan puncak Gunung Merapi. Wilayah ini berpotensi terlanda awan panas, aliran lava, guguran lava, lontaran batu pijar, serta gas beracun (Badan Penanggulangan Bencana Nasional, 2017).

Menurut Sinam, aktivis sosial setempat (interview 4 September 2018), pada tahun 1954 wilayah ini pernah terkena dampak parah dari letusan Gunung Merapi, di mana satu kampung musnah. Jarak dengan kota kabupaten Boyolali $41 \mathrm{~km}$ yang bisa ditempuh sekitar 75 menit. Jalan menuju pelosok desa sudah beraspal, sebagian merupakan jalan semen yang relatif bagus yang bisa dilalui kendaraan besar (truk). Terdapat beberapa temuan menarik terkait dengan kondisi perempuan di wilayah rawan bencana saat penggalian data, yaitu:

\section{Pernikahan Dini}

Persoalan pernikahan dini masih dominan di Tlogolele dan Klakah. Aparat desa mengakui bahwa persoalan pernikahan dini masih cukup banyak ditemui di wilayahnya. Walau sudah diberi sosialisasi aspek hukum dan kesehatan, fenomena ini tetap berlanjut. Ketika dihambat dengan peraturan hukum, mereka memilih "sidang", artinya menempuh jalur pengadilan agama untuk memperoleh dispensasi. 
Di Tlogolele, sampai bulan Maret 2018, sudah ada permintaan tiga dispensasi untuk pernikahan dini. Selain dispensasi, untuk mensiasati aturan tersebut, pemerintah desa juga melakukan penundaan pencatatan sipil sampai usia yang diperbolehkan UU sehingga warga cenderung melakukan pernikahan siri dahulu. Salah satu peserta FGD, Suji, menyatakan bahwa mereka tidak perlu kuatir cepat menikah dengan alasan, "Kalau ndang nikah, urip iso mapan" (Kalau segera menikah, hidup lebih mapan-red). Mengingat uang relatif mudah didapat dari pertambangan pasir.

Menurut data Kecamatan Selo dalam Angka Tahun 2017, jumlah pernikahan antara pernikahan membayar (pernikahan di bawah umur) lebih tinggi dibandingkan tidak membayar. Dijelaskan oleh salah satu petugas kecamatan, membayar artinya pernikahan siri karena ada persyaratan yang tidak terpenuhi atau usia masih di bawah yang dipersyaratkan. Artinya bahwa realitas ini masuk dalam kategori pernikahan dini. Data pada tahun 2014 menunjukkan jumlah 361 pernikahan dengan membayar, tahun 2015 sebanyak 262, dan tahun 2016 menurun menjadi 140.

Diagram 1 menunjukkan jumlah pernikahan dini sebanyak $63 \%$, dan angka

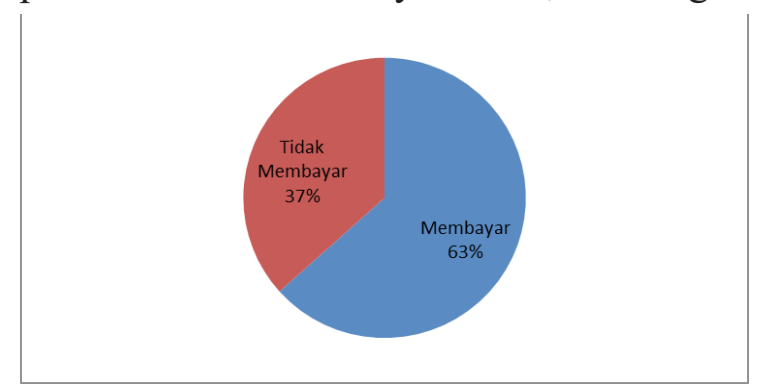

Diagram 1. Jumlah Pernikahan Pada Tahun 2016

Sumber: Dinas Komunikasi dan Informatika Kabupaten Boyolali, 2017

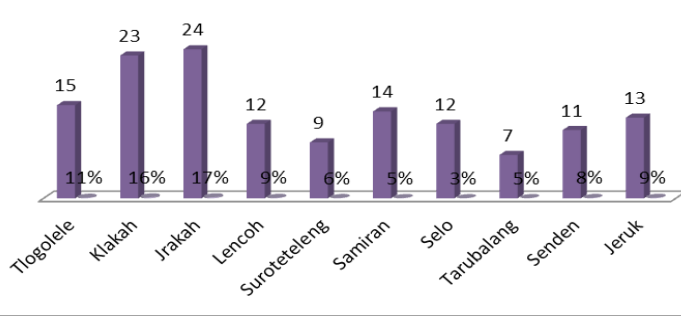

Diagram 2. Data Pernikahan Tahun 2016 Berdasarkan Wilayah

Sumber: Dinas Komunikasi dan Informatika Kabupaten Boyolali, 2017

ini lebih tinggi dibandingkan dengan pernikahan yang dilakukan sesuai dengan peraturan yang dipersyaratkan. Bila dilihat secara detail berdasarkan wilayah, angka pernikahan di bawah umur yang tergolong tinggi adalah Jrakah, Klakah, dan Tlogolele. Ketiganya secara berurutan mencapai angka $17 \%, 16 \%$ dan $11 \%$, seperti yang tersaji pada Diagram 2.

Tingginya angka pernikahan dini faktor utamanya adalah keluarga. Alasan keluarga menikahkan anaknya dalam usia dini antara lain soal rasa malu kalau anak gadisnya tidak segera menikah. Jika seorang gadis di usia dua puluh tahun belum menikah akan dianggap "tidak laku”. Nampaknya status demikian membuat tidak nyaman keluarga dan gadis yang bersangkutan sehingga warga masyarakat lebih memilih melakukan pernikahan dini. Keinginan untuk menikah dini bahkan mengalahkan keinginan untuk memperoleh pendidikan dan menikmati masa remaja, seperti gadis-gadis di wilayah lain (bahkan di tetangga desa).

Salah seorang narasumber FGD yang berusia 22 tahun, asal dusun Sumber, mengakui fenomena pernikahan dini sebagai suatu yang lumrah di desanya. Narasumber ini mengaku sudah memiliki anak usia delapan tahun. Artinya yang bersangkutan 
melahirkan saat usia 14 tahun. Baginya fenomena ini perlu diubah, sehingga saat ini yang bersangkutan menjadi salah satu kader Keluarga Berencana tingkat desa yang mempromosikan kesejahteraan keluarga.

Bagi warga, menyekolahkan anak membutuhkan biaya besar. Secara ekstrim warga menggambarkan bahwa daripada mengeluarkan biaya sekolah, warga lebih baik membeli sapi. Menurut narasumber lainnya bahwa posisi perempuan adalah di dapur, ibu rumah tangga sehingga tidak perlu sekolah tinggi. Namun di sisi lain, warga bersedia mengeluarkan uang banyak untuk biaya pesta pernikahan. Di Klakah,

"Warga tidak sayang mengeluarkan uang untuk pesta pernikahan dibandingkan mengeluarkan uang untuk biaya pendidikan," sebut salah satu sumber (Wawancara tanggal 21 April 2018).

Diagram 3 menunjukkan bahwa kecenderung tingkat pendidikan untuk Desa Tlogolele, Klakah, Jrakah, dan Lencoh masih rendah. Semakin tinggi tingkat pendidikan maka jumlahnya akan semakin mengalami penurunan. Berdasar tabel kecenderungan yang dominan adalah data penduduk dengan tingkat pendidikan Sekolah Dasar (SD) dan tidak/ belum tamat SD.

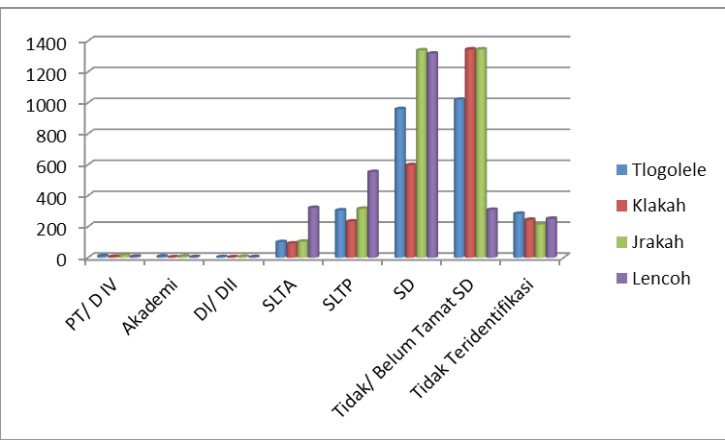

Diagram 3. Data Penduduk Berdasar Tingkat Pendidikan

Sumber: Dinas Komunikasi dan Informatika Kabupaten Boyolali, 2017

\section{Bencana dan Sustainabilitas}

Pada masyarakat desa Klakah, usaha untuk membuat ketahanan ekonomi warga terutama perempuan dengan mengadakan kegiatan ekonomi rumah tangga berupa makanan kering atau camilan tidak berkembang karena kalah dengan godaan penghasilan dari tambang pasir. Ibu-ibu tidak tertarik mengembangkan karena saat panen pasir, para suami bisa menghasilkan uang banyak, sedangkan uang hasil dari usaha makanan dianggap terlalu kecil. Di sini nampaknya warga masih berpikir jangka pendek bukan jangka panjang untuk menjamin pemasukan dari sektor usaha lain. Bahaya jangka panjang dari penambangan pasir adalah rusaknya lingkungan karena godaan untuk melakukan penggalian dengan alat-alat berat. Namun warga tidak kuatir dengan penghasilan dari pasir karena mereka percaya akan berkah Gunung Merapi, yang secara periodik akan memberikan pasir pada setiap erupsinya. Oleh karena itu, warga melihat Gunung Merapi tidak hanya sebagai bahaya namun juga sebagai pemberi berkah (rejeki).

Pernikahan dini dan pertambangan saling terkait karena pertambangan memberi pandangan mudahnya mencari uang secara cepat sehingga sebagian warga tidak kuatir akan pemasukan rumah tangga jika mereka melakukan pernikahan dini. Hal ini membuat sekolah tidak populer karena hanya dipandang sekolah/pendidikan terkait langsung untuk mencari pekerjaan. Padahal pendidikan disadari oleh ibu-ibu peserta 
FGD sebagai investasi jangka panjang, yang dapat membantu kesejahteraan warga di masa depan. Pendidikan tidak hanya dilihat sebagai soal manfaat untuk mencari uang (pekerjaan) namun juga soal peningkatan kualitas sumber daya manusia di desa. Namun pemikiran seperti ini belum sepenuhnya diterima mengingat hasilnya tidak langsung terlihat.

Menurut Mujianto (wawancara pada 21 April 2018) bahwa pertambangan membawa dampak sosial bagi warga. Pada saat puncak pertambangan pasir, banyak perubahan sosial terjadi. Seperti yang diungkapkan,

"Sampai anak kecil pun sudah bisa memegang uang."

Dahulu dalam satu hari bisa 1000 truk membawa pasir dr Sungai Apu. Jalanan desa menjadi riuh dengan lalu-lalang truk pengangkut pasir sepanjang 24 jam. Kesulitan lebih besar dihadapi di Klakah terkait penambangan pasir karena mudahnya akses ke lokasi pertambangan. Segala kegiatan di desa seperti terpusat di pertambangan pasir. Bahkan upaya rumah produksi makanan ringan terhenti karena booming pertambangan pasir.

Terkait dengan penambangan pasir, ada kesadaran akan adanya kemungkinan potensi bahaya baik secara sosial-ekonomi dan lingkungan. Pada tahun 2016, kepala Desa Tlogolele dan Klakah mengeluarkan pernyataan akan mengundurkan diri jika pertambangan pasir tetap berjalan. Potensi konflik muncul akibat penambangan pasir (metrojateng.com, 2016).

\section{Lebih Senang Menunggu dibanding Membangun Peluang}

Desa Jrakah dan Lencoh tidak memiliki problem pernikahan dini dan pertambangan seperti di Tlogolele dan Klakah. Kesadaran untuk pendidikan relatif terbuka. Hal ini nampaknya dipengaruhi lokasi desa yang relatif terbuka untuk berhubungan dengan masyarakat luar karena terletak di pinggir jalan Solo-Boyolali-Magelang. Selain itu, di Jrakah juga terdapat obyek wisata New Selo, lokasi untuk pendakian Gunung Merapi.

Namun letak yang relatif strategis ini belum sepenuhnya memberi perubahan ekonomi dari sumber daya alam (SDA) yang dimiliki, misalnya memikirkan soal peluang memberi nilai tambah hasil pertanian melalui produk olahan. Berdasar wawancara yang dilakukan dengan Yuli, seorang guru TK pada 22 April 2018 menyatakan bahwa di desa tersebut pernah ada pelatihanpelatihan untuk membuat produk olahan makanan berupa makanan ringan dari sayur-sayuran, seperti ceriping dan stick. Namun tindak lanjut pelatihan untuk memproduksi makanan ringan belum pernah dilakukan karena kuatir akan kemungkinan pemasarannya.

"Layu sebelum berkembang," menurutnya (Wawancara tanggal 21 April 2018).

Pemasaran produk pertanian, seperti sayur, masih berlangsung secara tradisional. Panenan dikumpulkan ke pengepul lalu dibawa ke kota besar yakni Magelang. Penentuan harga tergantung pada harga jual di pasaran (Magelang). Harga tersebut berdasar pengakuan pengepul dan petani akan menerima harga tersebut. Pada proses transaksi antara petani dan pengepul ini, 
unsur "trust" terjadi di sini. Berbeda dengan kondisi di Desa Lencoh, di desa ini lebih banyak dipengaruhi oleh keberadaannya sebagai lokasi pusat kecamatan. Ini memberi dampak akan sifat keterbukaan dalam berinteraksi antar warga. Termasuk kesadaran untuk menempuh pendidikan ke jenjang yang lebih tinggi semakin banyak.

Realitas yang terjadi di sebagian desa di Kecamatan Selo merupakan salah satu kondisi yang bisa dikatakan memprihatinkan. Ini bisa jadi hanya satu dari sekian kondisi penduduk di wilayah rawan bencana yang teridentifikasi. Problematika yang dijumpai di lokasi penelitian menjadi relevan untuk dikaji berdasarkan konsep self-concept. Konsep yang dikembangkan oleh Mead bahwa self-concept berarti bagaimana seorang individu mememiliki persepsi yang relatif stabil tentang diri sendiri (West \& Turner, 2010). Anggapan yang terjadi pada sebagian besar masyarakat di daerah rawan bencana Gunung Merapi ini merupakan bagian dari konsep diri warga masyarakat di sana. Misalnya pandangan bahwa ketika anak berusia sampai dua puluan tahun belum menikah dianggap "tidak laku" menjadi sesuatu yang kemudian tertanam pada masing-masing individu terutama para orang tua.

Secara lebih mendalam, realita perempuan di daerah rawan bencana ini terkait dengan komponen yang ada dalam konsep diri yaitu attitude, beliefs dan values (Beebe et al., 2010). Pandangan masyarakat mengenai pernikahan dini seolah menjadi sesuatu yang wajar bagi masyarakat setempat. Implikasinya bahwa ini menjadi hal yang kemudian diyakini dan seolah sebagai sebuah nilai yang dilegalkan oleh masyarakat secara umum. Pengambilan sikap pada sebagain besar orang tua untuk menikahkan anak perempuan di usia muda hingga akhirnya juga tidak menjadi persoalan di lingkungan masyarakat daerah rawan bencana ini.

Dinamika yang terjadi di wilayah itu mempengaruhi bagaimana proses interaksi yang ada antar individu satu dengan lainnya yang akhirnya mempengaruhi bagaimana konsep diri terjadi. Mulai dari lingkungan keluarga hingga masyarakat mempengaruhi pengambilan keputusan untuk memperlakukan anak-anaknya. Berdasarkan data temuan bahwa persoalan pernikahan dini nampaknya dipengaruhi pertimbangan sosial, budaya dan ekonomi.

Secara sosial, posisi perempuan ditempatkan sebagai pelaku di wilayah domestik. Tugasnya adalah mendukung suami, termasuk mencari nafkah di ladang, sehingga pengembangan diri secara individual (misal sekolah) dianggap tidak penting. Bagi sebagian warga, berkeluarga dengan pernikahan dini akan membantu dalam menata hidup sendiri.

"Nanti akan mapan setelah menikah," menurut salah seorang sumber (wawancara, 21 April 2018).

Menikah dahulu baru menata hidup, bukan sebaliknya seperti di wilayah lain yang berpandangan bahwa menikah baru dilakukan setelah melakukan persiapan (mapan). Artinya, pada kasus di wilayah penelitian ini, pernikahan dini menjadi pintu untuk menata kehidupan yang lebih mapan. 
Perempuan di sini memiliki peran ganda, tidak hanya mengurus anak, memasak, dan mengurus rumah namun juga bekerja di ladang. Ketika usia menikah masih terlalu muda (dini) maka potensi risiko kesehatan (melahirkan saat sangat muda), beban tugas ganda serta keterbatasan pendidikan akan dihadapi. Kesibukan yang dialami berpotensi membatasi ruang gerak mereka untuk mendapat peluang penambahan pengetahuan, termasuk soal bencana. Akhirnya perempuan menjadi peserta minoritas dalam pelatihan pengurangan risiko bencana.

Persoalan ini menjadi persoalan perempuan yang perlu diperhatikan sebagai bagian dari upaya pemberdayaan perempuan di wilayah bencana. Bila berpijak pada konsep gender, terdapat beberapa bentuk ketidakadilan yang kemudian dialami oleh perempuan di wilayah ini. Subordinasi terjadi ketika masyarakat menganggap bahwa salah satu jenis kelamin lebih penting dibandingkan jenis kelamin lainnya (Boyle, 2005; Lips, 2008; Widyastuti, Dhyah A.R., Thomas Adi P.S., Ranggabumi, 2018). Begitu juga yang terjadi di keempat desa di Kecamatan Selo ini, menganggap laki-laki lebih utama daripada perempuan sehingga anggapan pendidikan bagi perempuan tidak penting menjadi sesuatu yang wajar. Selain itu bentuk marginalisasi menjadi dominan, kecenderungan warga menempatkan perempuan untuk bekerja di wilayah domestik sebagai ibu rumah tangga.

Ketimpangan ini menjadi bagian dari bentuk-bentuk kekerasan yang terjadi pada perempuan. Merujuk pada hasil Pusat Riset
United Nations Children's Fund, bahwa kekerasan terhadap perempuan hadir di setiap negara, melintas batas budaya, kelas, pendidikan, pendapatan, dan usia (UNICEF, 2000). Atas dasar ini, pemberdayaan perempuan menjadi hal yang krusial dilakukan bagi perempuan di daerah rawan bencana. Pemberdayaan perempuan secara prinsip sebagai upaya untuk mencapai kesetaraan gender. Hal ini bisa melalui gagasan atau advokasi komunitas dana atau program dari pemerintah pusat maupun daerah baik dalam bidang kesehatan, pendidikan, kesejahteraan perempuan (United Nations Development Fund for Women, 2010).

Jika selama ini pemerintah menggalakkan pendidikan sebagai jalur meningkatkan taraf hidup, namun warga di desa ini berpikir berbeda. Kalau sekolah nantinya untuk bekerja, maka bagi mereka pekerjaan sudah ada tanpa mereka sekolah tinggi. Apalagi kalau melihat bahwa tidak otomatis mereka yang sekolah tinggi langsung mendapat pekerjaan. Data ini pun ditunjukkan oleh Data Kecamatan Selo dalam Angka Tahun 2017 bahwa kecenderungan pendidikan yang ditempuh oleh sebagian masyarakat hanya sampai dengan jenjang Sekolah Dasar.

Nampaknya warga tidak terlalu mengkuatirkan persoalan ekonomi untuk penopang rumah tangganya, mengingat alam di sekitar yang sudah dianggap dapat mencukupi kebutuhan. Pasir dari Gunung Merapi, misalnya, dapat memberi penghasilan yang lumayan bagi warga. Bahkan dicontohkan oleh narasumber, anak 
usia sekolah saja sudah dapat memiliki penghasilan sendiri asal sudah bisa membawa "serok" pasir. Selain itu, warga mendapat penghasilan dari lahan kebun sayur dan tembakau di lereng Merapi. Sejak lulus SD, bagi anak perempuan yang tidak melanjutkan ke SMP, akan diajari berladang membantu nafkah keluarga. Nampaknya warga melihat fenomena pernikahan dini lebih difokuskan pada soal ekonomi.

Fenomena pernikahan dini di wilayah Selo, khususnya desa Jrakah dan Klakah dapat dijelaskan bahwa motif melakukan pernikahan dini adalah hasil dari nilai dan norma yang hidup di masyarakat sana sehingga self-concept yang dimiliki para pelaku membuat penilaian terhadap pernikahan dinibisaberbedadenganpenilaian masyarakat di luar mereka (Oyserman et al., 2012). Berbagai hasil studi yang dikaji oleh Parsons menunjukkan bahwa norma sosial, budaya, ekonomi, pendidikan serta konteks komunitasnya memberi pengaruh pada pandangan para gadis untuk menikah dini (Parsons et al., 2015).

Situasi berbeda di desa Jrakah dan Lencoh. Pusat dua desa ini lebih mudah diakses karena dilalui oleh jalan provinsi yang menghubungkan Solo-Boyolali dan Magelang. Akhirnya, kedua desa ini relatif lebih sering kontak dengan masyarakat luas. Apalagi terdapat sebuah lembaga swadaya masyarakat yang sudah mendampingi mereka selama belasan tahun. Perjumpaan dengan masyarakat luar membantu warga untuk terbuka pada perubahan. Kasus pernikahan dini di kedua desa jarang terjadi. Mengirim anak untuk memperoleh pendidikan lebih tinggi menjadi salah satu cara untuk mengurangi pernikahan dini.

Lokasiyangdekatdengankota-kota besar di Jawa, seperti Yogya, Solo dan Semarang (terkenal dengan sebutan Joglosemar), tidak pelak lagi setiap peristiwa letusan Gunung Merapi mendapat perhatian besar. Tidak mengherankan jika kawasan rawan bencana Gunung Merapi telah memperoleh berbagai kajian penelitian. Pengurangan risiko bencana secara jangka panjang harus dilakukan. Hal tersebut dilakukan melalui pemberdayaan masyarakat, suatu topik yang menjadi fokus dari sekelompok peneliti Institut Teknologi Bandung (Sagala dkk, 2014), yang menemukan perlindungan sosial merupakan hal penting di dalam membangun masyarakat tangguh untuk pengurangan risiko bencana. Perlindungan sosial berfungsi mengurangi kerentanan di masyarakat yang tinggal di kawasan rawan bencana. Tuswadi \& Hayashi (2014) mendalami aspek pendidikan pencegahan bahaya Merapi di kalangan siswa sekolah menengah di kawasan rawan bencana Merapi. Hasil penelitian survei, keduanya menemukan bahwa para siswa sudah belajar tentang bahaya Merapi namun pengajaran soal ini masih belum efektif mengingat penggunaan materi ajar dan kekurangan pengetahuan para guru. Aspek pendidikan kebencanaan juga diteliti oleh Handitcianawati dkk. (2018) di wilayah Klaten, khususnya terkait dengan kesiapsiagaan pada sekolahsekolah di wilayah bencana. Hasil penelitian tersebut menemukan bahwa responden berada di situasi siap menghadapi bencana. Pada aspek inovasi dan komunikasi, 
Wardyaningrum (2014) mendalami bagaimana masyarakat melakukan inovasi dalam komunikasi setelah peristiwa letusan Merapi 2010. Wilayah yang diteliti adalah sisi Merapi bagian kabupaten Klaten. Peneliti menganalis masalah ini melalui penggunaan teori difusi inovasi. Selain itu kajian mengenai dinamika perempuan menjadi topik menarik di beberapa studi. Seperti kajian mengenai realitas perempuan di tambang di mana kehidupan di area ini melihat bahwa kesetaraan antara perempuan dan laki-laki bisa dikatakan sebagai sebuah kesetaraan mutlak. Perempuan di tambang mampu bertahan di tengah pekerjaan yang didominasi oleh laki-laki (Mahmudah, 2019). Di sisi lain Ganiem (2017) melihat bahwa pemberdayaan perempuan melalui pendidikan nonformal adalah penting dan berdampak positif dengan mempertimbangkan kebutuhan masyarakat setempat.

\section{Simpulan}

Berdasarkan uraian data sesuai pada temuan di lapangan maka dapat disimpulkan bahwa terdapat berbagai konsep diri yang terbentuk pada perempuan di kawasan rawan bencana Gunung Merapi yakni cenderung menikah di usia dini, menganggap pendidikan tidak penting, hingga keterbatasan dalam akses ekonomi yang seolah dianggap wajar dan bersikap pasrah. Perempuan di kawasan lereng Gunung Merapi menilai tujuan hidup adalah sebagai ibu rumah tangga sehingga orientasi tindakan yang terwujud adalah munculnya fenomena di sebagian perempuan untuk melakukan pernikahan dini, tidak mengutamakan pendidikan. Pernikahan dini dianggap sebagai tradisi yang harus mereka terima. Mereka memandang takdir sebagai perempuan adalah segera menikah untuk menghindari hal-hal buruk yang terjadi seperti perzinaan dan menanggung malu jika menjadi perawan tua. Peran ganda dalam urusan rumah tangga serta membantu mencari nafkah di ladang membuat mereka penuh kesibukan. Kesibukan yang dialami berpotensi membatasi ruang gerak mereka untuk mendapat peluang penambahan pengetahuan, termasuk soal pengurangan risiko bencana, suatu pengetahuan yang sangat penting di daerah mereka tinggal. Atas dasar kajian ini harapannya manajemen risiko bencana menjadi perhatian penting untuk lebih sensitif dan peka terhadap persoalan perempuan. Kesejahteraan dan kebutuhan baik perempuan dan laki-laki dapat diatasi secara berimbang antara satu dengan lainnya.

Konsep diri menjadi bagian yang penting dalam perbaikan posisi perempuan di lokasi penelitian, dan hal ini tergantung pada wawasan yang dimiliki oleh individu yang bersangkutan dan warga. Perluasan wawasan dapat diperoleh melalui jalur pendidikan baik melalui lembaga formal (sekolah) maupun informal (kegiatan kelompok perempuan) yang bisa digerakkan oleh pemimpin organisasi perempuan setempat. Khusus dalam penelitian ini, pemberdayaan kelompok perempuan menjadi hal yang strategis untuk dilakukan.

\section{Daftar Pustaka}

Amri, M. R., Yulianti, G., Yunus, R., Wiguna, S., Adi, A. W., Ichwana, A. N., Septian, R. T. (2016). Risiko Bencana Indonesia 
(R. Jati \& M. R. Amri, Eds.). Retrieved from http://inarisk.bnpb.go.id/pdf/Buku RBI_Final_low.pdf

Ashraf, M. A., \& Azad, M. A. K. (2015). Gender Issues in Disaster: Understanding the Relationships of Vulnerability, Preparedness and Capacity. Environment and Ecology Research, 3(5), 136142. https://doi.org/10.13189/ eer.2015.030504

Badan Penanggulangan Bencana Nasional. (2017). Buku Saku Tanggap Tangkas Tangguh Menghadapi Bencana (2017th ed.). Retrieved from https://siaga. bnpb.go.id/hkb/po-content/uploads/ documents/Buku_Saku-10Jan18_FA.pdf

Beebe, S. A., Beebe Susan J., \& Diana K Ivy. (2010). Communication Principles for A Lifetime. Boston: Pearson Education, Inc.

Boyle, K. (2005). Media and Violence, Gendering the Debates. London: Sage.

Enarson, E. (2009). Women Building their Future: Gender Breakthroughs in PostTsunamiAceh (S. Fortuna, Ed.). Retrieved from https://www.preventionweb.net/ files/19842_unifemenarsonacehgenderb reakthrough.pdf

ESCAP, \& UNISDR. (2012). The AsiaPacific Disaster Report 2012: Reducing Vulnerability and Exposure to Disasters. United Nations.

Flick, U. . (2002). An Introduction to Qualitative Research. ThousandOaks, California: Sage.

Ganiem, Leila Mona. (2017). Pemberdayaan Perempuan Miskin Kota Melalui Pendidikan. Jurnal ASPIKOM, Volume 3 Nomor 2, Hal 239-255.

Handitchianawati, Wiwin, Rose Ana Anggun Fajariah, Ayu Fatonah, Eka Wulan Safriani, Nanda Khoirunisa. (2018).
Seminar Nasional dan Geografi dan Pembangunan Berkelanjutan. Hal: 147-156.

Hazeleger, T. (2013). Gender and disaster recovery: Strategic issues and action in Australia. Australian Journal of Emergency Management, 28(2), 40-46.

Kemenpppa. (2011). Gender Dalam Bencana Alam dan Adaptasi Iklim. Retrieved from http://www.kemenpppa.go.id/lib/ uploads/list/c3b33-6.-gender-dalambencana-alam-dan-adaptasi-iklim.pdf

Kibria, G. (2016). Why are women in developing countries more vulnerable to climate Change? Climate change implications on women with reference to food, water, energy, health, and disaster security. Https://Www.Researchgate. Net/Publication/267072733_Why_Are Women_More_Vulnerable_to_Climate Change. https://doi.org/10.13140/ RG.2.1.2577.9683.

Kusumayudha, Sari Bahagiarti, Puji Lestari, dan Eko Teguh Paripurno. (2018). Eruption Characteristic of the Sleeping Volcano, Sinabung, North Sumatra, Indonesia, and SMS gateway for Disaster Early Warning System. Indonesian Journal of Geography Vo. 50, No. 1, Page 70-77.

Lestari, Puji, Sari Bagiarti Kusumayudha, Eko Teguh Paripurno, Herlina Jayadianti. (2016). Environmental Communication Model for Disaster Mitigation of Mount Sinabung Eruption Karo Regency of North Sumatra. Information Volume 19, Number 9 (B). Page 4265-4270.

Lips, H. (2008). Sex and Gender An Introduction. New York: McGraw Hill.

metrojateng.com. (2016, June 20). N. Retrieved from https://metrojateng.com/ dua-kades-di-boyolali-mengundurkandiri-ada-apa/ 
Mahmudah, Zulfatun. (2019). Pekerja Perempuan di Tambang: Bentuk Negosiasi Kesetaraan Gender dalam Dunia Kerja Maskulin. Jurnal Aspikom, Vol. 3 No. 6, Hal 1228-1242.

Moreno, J., \& Shaw, D. (2018). Women's empowerment following disaster: a longitudinal study of social change. Natural Hazards, 92(1), 205-224. https:// doi.org/10.1007/s11069-018-3204-4

Neumayer, E., \& Plümper, T. (2007). The Gendered Nature of Natural Disasters: The Impact of Catastrophic Events on The Gender Gap in Life Expectancy, 1981-2002. Annals of the Association of American Geographers. https://doi. org/10.1111/j.1467-8306.2007.00563.x

Oyserman, D., Elmore, K. C., \& Smith, G. C. (2012). Handbook of Self and Identity. Edited by Mark R. Leary June Price Tangney. In Handbook of Self and Identity. https://doi.org/10.1300/ J082v10n03_13

Parsons, J., Edmeades, J., Kes, A., Petroni, S., Sexton, M., \& Wodon, Q. (2015). Economic Impacts of Child Marriage: A Review of the Literature. The Review of Faith \& International Affairs, 13(3), 12 22. https://doi.org/10.1080/15570274.20 15.1075757

Pincha, C. (2008). Penanggulangan Bencana yang Peka Gender, Sebuah perangkat untuk Para Praktisi. Retrieved from http://gdnonline.org/resources/Pincha_ GenderSensitiveDM_BahasaIndonesia. pdf

Sagala, Saut, Dkk. (2014). Social Protection Roles in Reducing Risk and Building Resilience to Communities in Indonesia. Resilien Development Initiatives. Working Paper Series No. 11 Agustus 2014.
Sulistiyono, S. T. (2017). BNPB Mencatat Bencana 2017. Retrieved from https://nasional.kompas.com/ $\mathrm{read} / 2017 / 12 / 21 / 17505651 / \mathrm{bnpb}-$ mencatat-ada-2271-bencana-alamsepanjang-2017.

Tanesia, A. (2007). Women, Community Radio, and Post-Disaster Recovery Process. Women in Action, 2, 68-76. Retrieved from https://www.isiswomen. org/index.php?option=Com_content\&vi ew $=$ article $\& \mathrm{id}=891 \&$ Itemid $=346$

Tuswadi, Takehiro Hayashi. (2014). Disaster Prevention Education in Merapi Volcano Area Primary Schools: Focusing on Students' Perception and Teachers' Performance. Procedia Environmental Sciences 20 (2014) Page: 668-677.

UNESCO. (n.d.-a). Gender Equality and Disaster Risk Reduction: facts and figures. Retrieved August 5, 2018, from UNESCO website: http://www.unesco.org/new/en/ natural-sciences/priority-areas/genderand-science/cross-cutting-issues/genderequality-and-disaster-risk-reduction/ facts-and-figures/

UNESCO. (n.d.-b). Gender Equality and Disaster Risk Reduction. Retrieved August 5, 2018, from UNESCO website: http://www.unesco.org/new/en/naturalsciences/priority-areas/gender-andscience/cross-cutting-issues/genderequality-and-disaster-risk-reduction/

UNICEF. (2000). Domestic Violence Against Women And Girls. Retrieved from https:// www.unicef.org/malaysia/ID_2000_ Domestic_Violence_Women_Girls_6e. pdf

United Nations Development Fund for Women. (2010). Women 's Empowerment Principles Equality Means Business. Retrieved from https://www. unglobalcompact.org/docs/issues_doc/ 
human_rights/Resources/WEP_EMB_ Booklet.pdf

Wardyaningrum, Damayanti. 2014. Perubahan Komunikasi Masyarakat dalam Inovasi Mitigasi Bencana di Wilayah Rawan Bencana Gunung Merapi. Jurnal ASPIKOM Vol 2. No. 3, Juli 2014, Hal: 179-197.

West, R. L., \& Turner, L. H. (2010). Introducing Communication Theory:
Analysis and Application. In McGrawHill. (4th ed.). Boston: McGraw-Hill.

Widyastuti, Dhyah A.R., Thomas Adi P.S., Ranggabumi, N. (2018). Literasi Digital: Upaya Mengembangkan UMKM di Era Digital. Yogyakarta: Buku Litera.

Women, F. (2013). practical stories. Australian Journal of Emergency Management, 28(2), 47-48. 